\title{
Anarchist Sociology and the Legacy of Peter Kropotkin
}

\author{
Gary L. Grizzle*
}

To date, anarchist thought has received little attention in mainstream sociology owing in large part to the failure of anarchist scholars to articulate an analytical perspective on par with those that currently define our discipline. This work suggests that the views of the Russian anarchist Peter Kropotkin (1842-1921) provide a useful foundation for the development of such a perspective. To that end, the author provides a synopsis of Kropotkin's views on social analysis; proffers a rudimentary anarchist analytical framework derived from those views; delineates the most important merits of the proposed framework as a basis for the practice of sociology; and comments on the future of Kropotkian anarchist sociology. [Article copies available for a fee from The Transformative Studies Institute. E-mail address: journal@transformativestudies.org Website: http://www.transformativestudies.org (C2017 by The Transformative Studies Institute. All rights reserved.]

KEYWORDS: Peter Kropotkin, Anarchist Sociology, Sociological Theory.

Despite the relevance of their views to understanding society, anarchist theorists had little influence on the early development of the social sciences. Mac Laughlin (1986) attributed this to the fact that these sciences were established in State supported institutions in the latter half of the nineteenth century; a context in which the nation-state was assumed to be both natural and progressive. Consequently, he claimed, the nascent social sciences excluded anarchists from their ranks, having deemed them traitorous and their ideas utopian. While deliberate disregard for anarchists and their ideas is no doubt less common today

\footnotetext{
* Gary L. Grizzle has a Ph.D. in Sociology from Northwestern University and is currently Associate Professor and Chair, Department of Sociology \& Criminology, Barry University. His research interests include marriage and the family, religion, urban myths, and anarchist theory. Address correspondence to: Gary Grizzle, Department of Sociology and Criminology, Barry University, 11300 Northeast Second Avenue, Miami Shores, FL 33161; e-mail: ggrizzle@barry.edu.
} 